\title{
Ancient feeding ecology inferred from stable isotopic evidence from fossil horses in South America over the past $3 \mathrm{Ma}$
}

\author{
José L Prado ${ }^{1}$, Begoña Sánchez ${ }^{2}$ and María T Alberdi ${ }^{*}$
}

\begin{abstract}
Background: Stable isotope ratios $\left({ }^{13} \mathrm{C} /{ }^{12} \mathrm{C}\right.$ and $\left.{ }^{18} \mathrm{O} /{ }^{16} \mathrm{O}\right)$ in fossil teeth and bone provide key archives for understanding the ecology of extinct horses during the Plio-Pleistocene in South America; however, what happened in areas of sympatry between Equus (Amerhippus) and Hippidion is less understood.

Results: Here, we use stable carbon and oxygen isotopes preserved in 67 fossil tooth and bone samples for seven species of horses from 25 different localities to document the magnitude of the dietary shifts of horses and ancient floral change during the Plio-Pleistocene. Dietary reconstructions inferred from stable isotopes of both genera of horses present in South America document dietary separation and environmental changes in ancient ecosystems, including $C_{3} / C_{4}$ transitions. Stable isotope data demonstrate changes in $C_{4}$ grass consumption, interspecies dietary partitioning and variation in isotopic niche breadth of mixed feeders with latitudinal gradient.

Conclusions: The data for Hippidion indicate a preference varying from $C_{3}$ plants to mixed $C_{3}-C_{4}$ plants in their diet. Equus (Amerhippus) shows three different patterns of dietary partitioning Equus (A.) neogeus from the province of Buenos Aires indicate a preference for $C_{3}$ plants in the diet. Equus (A.) andium from Ecuador and Equus (A.) insulatus from Bolivia show a preference for to a diet of mixed $C_{3}-C_{4}$ plants, while Equus (A.) santaeelenae from $L a$ Carolina (sea level of Ecuador) and Brazil are mostly $\mathrm{C}_{4}$ feeders. These results confirm that ancient feeding ecology cannot always be inferred from dental morphology. While the carbon isotope composition of horses skeletal material decreased as latitude increased, we found evidence of boundary between a mixed $C_{3} / C_{4}$ diet signal and a pure $C_{4}$ signal around $32^{\circ} \mathrm{S}$ and a change from a mixed diet signal to an exclusively $C_{3}$ signal around $35^{\circ} \mathrm{S}$. We found that the horses living at high altitudes and at low to middle latitude still have a $C_{4}$ component in their diet, except the specimens from $4000 \mathrm{~m}$, which have a pure $C_{3}$ diet. The change in altitudinal vegetation gradients during the Pleistocene is one of several possibilities to explain the $C_{4}$ dietary component in horses living at high altitudes. Other alternative explanations imply that the horses fed partially at lower altitudes.
\end{abstract}

Keywords: Stable Isotopes, $C_{4}$ plants, Mammals, horses, South America

\section{Background}

In South America, horses are represented by two groups: equidiforms and hippidiforms. Hippidion are characterized by a retracted nasal notch which has been interpreted as an adaptation to the presence of a proboscis and limbs with robust metapodials. The upper teeth present an elongate-oval protocone with simple

\footnotetext{
* Correspondence: malberdi@mncn.csic.es

${ }^{2}$ Museo Nacional de Ciencias Naturales, CSIC. José Gutiérrez Abascal, 2. 28006-Madrid, Spain

Full list of author information is available at the end of the article
}

enamel plication and lower teeth have a deep ectoflexid, penetrating the isthmus (Figure 1). On the other hand, in Equus (Amerhippus) a retracted nasal notch is not present and the metapodials are slender. The upper teeth present a triangular protocone and multiple internal posfossette plications. There are features that are common to both of these groups, such as differentiation into horses of both small and large body size, which are possibly a consequence of convergence due to adaptation to similar environments. The three species of hippidiforms are included within the genus Hippidion Owen, 1869
Ciomed Central

() 2011 Prado et al; licensee BioMed Central Ltd. This is an Open Access article distributed under the terms of the Creative Commons Attribution License (http://creativecommons.org/licenses/by/2.0), which permits unrestricted use, distribution, and reproduction in any medium, provided the original work is properly cited. 


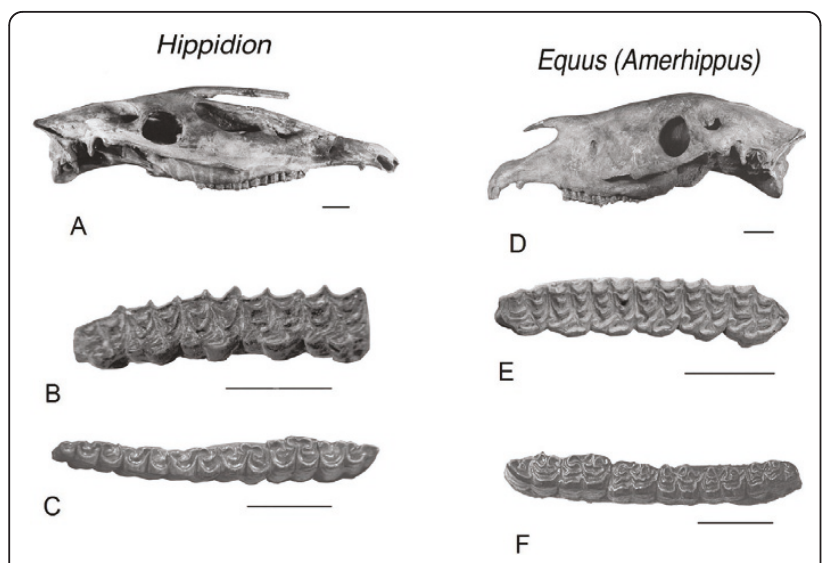

Figure 1 Skull and dental characteristics. A, Hippidion with nasal notch posterior to $\mathrm{M}_{1}$. B, Equus (Amerhippus). C, comparative morphology of upper cheek teeth in occlusal view.

$[1,2]$ whereas the five species of equidiforms are included in the subgenus Equus (Amerhippus) [3]. Each of these groups has different ecological adaptations that are evident in the cranial morphology, robustness of the limbs and body size $[4,5]$.

A technique that has proven useful for investigating the ecology of fossil horses is through examination of stable isotope values found in teeth and bone in combination with dental wear [6-16]. Isotopic analyses can reveal information about resource use and resource partitioning among species and is also able to determine diet and habitat use [15,17]. Here, we will address: (1) whether stable isotope values permit identification of resource use and partitioning among horse species and (2) if resource use and partitioning are determined, do the results support the ecology predicted by morphology or body size? Finally, we compare carbon isotope values and evaluate the hypothesis that dietary niches, inferred from the mean and variation of carbon isotope values, did not change throughout time in the same latitude.

Stable carbon and oxygen isotopes are incorporated into the tooth and bone apatite of horses and are representative, respectively, of the food and water consumed while alive. The carbon isotope ratio is influenced by the type of plant material ingested, which is in turn influenced by the photosynthetic pathway utilized by the plants. During photosynthesis, $\mathrm{C}_{3}$ plants in terrestrial ecosystems (trees, bushes, shrubs, forbs, and high altitude and high latitude grasses) discriminate more markedly against the heavy ${ }^{13} \mathrm{C}$ isotope during fixation of $\mathrm{CO}_{2}$ than $\mathrm{C}_{4}$ plants (tropical grasses and sedges). Thus $\mathrm{C}_{3}$ and $\mathrm{C}_{4}$ plants have distinct $\delta^{13} \mathrm{C}$ values. $\mathrm{C}_{3}$ plants usually have $\delta^{13} \mathrm{C}$ values of -30 per mil (\%o) to $-22 \%$, with an average of approximately $-26 \%$, whereas $\mathrm{C}_{4}$ plants have $\delta^{13} \mathrm{C}$ values of -14 to $-10 \%$, with an average of about -12\%o [18-22]. Animals incorporate carbon isotopes from food into their teeth and bone with an additional fractionation of $\sim 12$ to $14 \%$ [23,24]. Mammals feeding on $\mathrm{C}_{3}$ plants characteristically have $\delta^{13} \mathrm{C}$ values between -14 and $-8 \%$, while animals that eat $\mathrm{C}_{4}$ tropical grasses have $\delta^{13} \mathrm{C}$ values between +2 and $-2 \%$. A mixed-feeder would fall somewhere in between these two extremes $[25,26]$. Hence, the relative proportions of $\mathrm{C}_{3}$ and $\mathrm{C}_{4}$ vegetation in the diet of an animal can be determined by analyzing the $\delta^{13} \mathrm{C}$ value of its teeth and bones.

A number of previous studies have used the carbon and oxygen isotopic abundance of fossils and paleosols from South America to reconstruct the diets of extinct herbivores and the paleoenvironmental parameters of ancient terrestrial communities and ecosystems [27-32]. Carbon isotope data for horses from South America have been presented in several papers [8,33-35]. In 1999, MacFadden et al. [36] presented the ancient distributions and latitudinal gradients of $C_{3}$ and $C_{4}$ grasses based on isotopic data from New World Pleistocene horses. In addition, some papers have investigated the application of geochemical techniques in conjunction with morphological and dental wear data to reconstruct the feeding ecology and niche characterization of individual species [34,36,37].

All equid taxa from South America were sampled for teeth (n:29) and bone (n:38) stable carbon and oxygen isotopes (table 1 and 2). Additional data of thirty samples were taken from MacFadden et al. [36]. Together the data represent five species within the subgenus Equus (Amerhippus): E. (A.) andium, E. (A.) insulatus, E. (A.) neogeus, E. (A.) santaeelenae and E. (A.) lasallei [3]. The genus Hippidion includes three species: H. principale, $H$. devillei and $H$. saldiasi [2]. Some of these valid species have a wide geographical distribution whilst others, such as $E$. (A.) andium and $E$. (A.) insulatus, are restricted to the Andes region. In contrast, E. (A.) neogeus, E. (A.) santaeelenae and E. (A.) lasallei are found in the non-Andean tropical or subtropical regions of South America such as Argentina, Uruguay, Colombia, Brazil, and the coastal area of Ecuador (Figure 2). H. saldiasi is restricted to a particular habitat in southern Patagonia [38,39]; while $H$. principale and $H$. devillei come from different localities in South America, such as Tarija in Bolivia and the Pampa region in Argentina, that cover a broad range of altitudes from 10 to $4000 \mathrm{~m}$. One restriction to our study is the chronological control of the sample. Most of the samples were collected from old museum collections in Ecuador, Bolivia and Argentina. These old collections were recovered without sufficient stratigraphic control. Anyway we considered this limitation may condition the interpretations about altitudinal and latitudinal gradients for fossil samples, but do not invalidate the suggested patterns. 
Table 1 Values of $\delta^{18} \mathrm{O}$ and $\delta^{13} \mathrm{C}$ of South American fossil Hippidion.

\begin{tabular}{|c|c|c|c|c|c|c|c|c|}
\hline Species name (age) & $\begin{array}{l}\text { Specimen } \\
\text { number }\end{array}$ & $\begin{array}{c}\text { Skeletal } \\
\text { tissue }\end{array}$ & $\begin{array}{c}\text { Altitude } \\
\text { m.asl }\end{array}$ & Locality (country) & Latitude & $\begin{array}{c}\mathrm{d}^{13} \mathrm{C}\left(\mathrm{CO}_{3}\right) \\
\% \text { PDB }\end{array}$ & $\begin{array}{c}\mathrm{d}^{18} \mathrm{O}\left(\mathrm{PO}_{4}\right) \\
\% \text { \%-SMOW }\end{array}$ & $\begin{array}{c}\mathrm{d}^{18} \mathrm{O}\left(\mathrm{CO}_{3}\right) \\
\% \text { \%-SMOW }\end{array}$ \\
\hline H. devillei (44 to 21 ka BP) & MACN 1621 & $b$ & 1866 & Tarija (Bo) & 225 & -8.8 & 19.7 & 26.1 \\
\hline H. devillei (44 to 21 ka BP) & MACN 1516 & $\mathrm{t}$ & 1866 & Tarija (Bo) & $22 S$ & -10.8 & 19.3 & 28.7 \\
\hline "O". devillei (44 to 21 ka BP)" & & e & 1866 & Tarija (Bo) & $22 S$ & -6.6 & & \\
\hline H.principale (44 to $21 \mathrm{ka} \mathrm{BP})^{1}$ & & e & 1866 & Tarija (Bo) & 225 & -10.3 & & \\
\hline H.principale (44 to 21 ka BP) ${ }^{2}$ & & e & 1866 & Tarija (Bo) & $22 S$ & -8.8 & & \\
\hline H. devillei (12.8 to 11.5 ka BP) & MLP 85-VII-1-2 & $\mathrm{t}$ & 4000 & Mina Aguilar (Ar) & $23 S$ & -9.8 & 17.2 & 24.1 \\
\hline H. devillei (12.8 to 11.5 ka BP) & MLP 85-VII-1-4 & $b$ & 4000 & Mina Aguilar (Ar) & $23 S$ & -10.0 & 14.2 & 25.2 \\
\hline H. devillei (Late Plio) & MACN 5361 & $b$ & 4000 & Uquía (Ar) & 235 & -10.1 & 16.6 & 25.6 \\
\hline H. devillei (Late Plio) & MACN 5361 & $\mathrm{t}$ & 4000 & Uquía (Ar) & $23 \mathrm{~S}$ & -10.2 & 17.4 & 25.2 \\
\hline H. devillei (Late Plio) & MACN 5364 & $\mathrm{t}$ & 4000 & Uquía (Ar) & $23 S$ & -9.9 & 16.8 & 25.3 \\
\hline H. devillei (Late Plio) & MACN 5364 & $b$ & 4000 & Uquía (Ar) & $23 \mathrm{~S}$ & -10.3 & 16.0 & 25.9 \\
\hline H. devillei (Early PI) & MACN 2140 & $\mathrm{t}$ & 10 & Olivos (Ar) & $35 S$ & -9.8 & 21.5 & 29.8 \\
\hline H. devillei (Early PI) & MACN 2138 & $\mathrm{t}$ & 10 & Olivos (Ar) & $35 S$ & -11.7 & 20.2 & 28.8 \\
\hline H. devillei (Early PI) & MACN 2155 & $b$ & 10 & Olivos (Ar) & $35 S$ & -10.2 & 19.7 & 27.7 \\
\hline H. principale (Middle PI) & MLP 6-19 & $\mathrm{t}$ & 10 & Paraná (Ar) & 325 & -8.4 & 19.4 & 28.9 \\
\hline H. principale (Middle $\mathrm{Pl}$ ) & MLP 6-19 & $b$ & 10 & Paraná (Ar) & 325 & -8.7 & 19.1 & 29.3 \\
\hline H. principale (Early PI) $)^{3}$ & MLP 6-441 & e & 10 & Buenos Aires (Ar) & $35 S$ & -12.9 & & \\
\hline H. principale (Early PI) $)^{3}$ & MLP 6-435 & e & 10 & Buenos Aires (Ar) & $35 S$ & -10.2 & & \\
\hline H. principale (28 to $10 \mathrm{ka} \mathrm{BP}$ ) & MACN 10441 & e & 10 & Luján (Ar) & $35 S$ & -10.6 & 21.2 & 30.2 \\
\hline H. principale (28 to $10 \mathrm{ka} \mathrm{BP}$ ) & MACN 10441 & $d$ & 10 & Luján (Ar) & $35 S$ & -12.1 & 20.9 & 30.7 \\
\hline H. principale (28 to $10 \mathrm{ka} \mathrm{BP}$ ) & MLP 6-364 & $b$ & 10 & Luján (Ar) & $35 S$ & -11.3 & 19.5 & 30.6 \\
\hline H. principale (28 to $10 \mathrm{ka} \mathrm{BP}$ ) & MACN 6092 & $b$ & 10 & Luján (Ar) & $35 S$ & -11.2 & 21.7 & 30.5 \\
\hline H. principale (28 to $10 \mathrm{ka} \mathrm{BP}$ ) & MACN 5667 & $\mathrm{t}$ & 10 & Río Salado (Ar) & $36 S$ & -12.0 & 19.8 & 28.8 \\
\hline H. principale (28 to $10 \mathrm{ka} \mathrm{BP}$ ) & MACN 5667 & $b$ & 10 & Río Salado (Ar) & $36 S$ & -10.1 & 19.9 & 28.3 \\
\hline H. principale (28 to $10 \mathrm{ka} \mathrm{BP}$ ) & MACN 5056 & $\mathrm{~b}$ & 10 & Río Salado (Ar) & $36 S$ & -8.2 & 20.2 & 30.1 \\
\hline H. principale (28 to $10 \mathrm{ka} \mathrm{BP}$ ) & MACN 1735 & $\mathrm{t}$ & 50 & Arroyo Tapalqué (Ar) & 385 & -9.8 & 20.2 & 29.2 \\
\hline H. principale (28 to $10 \mathrm{ka} \mathrm{BP}$ ) & MACN 5265 & $b$ & 50 & Arroyo Tapalqué (Ar) & 385 & -9.6 & 20.1 & 29.1 \\
\hline H. principale (28 to $10 \mathrm{ka} \mathrm{BP}$ ) & MACN 1734 & $\mathrm{t}$ & 50 & Arroyo Tapalqué (Ar) & $38 \mathrm{~S}$ & -9.4 & 22.1 & 31.5 \\
\hline H. principale (28 to $10 \mathrm{ka} \mathrm{BP}$ ) & $s / s$ & $b$ & 100 & Arroyo Tapalqué (Ar) & $38 \mathrm{~S}$ & -11.6 & 19.5 & 30.8 \\
\hline H. principale (28 to $10 \mathrm{ka} \mathrm{BP}$ ) & MACN 9739 & $b$ & 100 & Río Quequén Salado(Ar) & 385 & -8.1 & 21.2 & 29.9 \\
\hline H. saldiasi (12.8 to $11.5 \mathrm{ka} \mathrm{BP)}$ & MLP 81-VI-28-5 & $b$ & 200 & U. Esperanza (Ch) & $52 S$ & -12.2 & 17.65 & 24.9 \\
\hline
\end{tabular}

Samples with the same "specimen number" correspond to the same individuals. The bones correspond to the mandibular or maxillary remains that contained the teeth that were analyzed. Plio = Pliocene; $\mathrm{PI}=$ Pleistocene; $\mathrm{e}=$ enamel; $\mathrm{d}=$ dentine; $\mathrm{b}=\mathrm{bone} ; \mathrm{t}=$ tooth (enamel + dentine). $\mathrm{Ar}=\mathrm{Argentina}$; Bo $=\mathrm{Bolivia}$; $\mathrm{Br}$ $=$ Brazil; $C h=$ Chile. A = Andean; PL = Plain landscape. ${ }^{1}$ Taken from MacFadden et al. [22], ${ }^{2}$ taken from MacFadden and Shockey [27] and ${ }^{3}$ taken from MacFadden et al. [20].

In order to demonstrate how dietary resources were partitioned we divided the samples into 10 different groups taking into account the genus, as well as the age and the altitude of the corresponding deposit. Data for these groups and descriptive statistics are listed in table 3: (A) all Hippidion; (B) all Equus (Amerhippus); (C) Hippidion from the Late Pleistocene; (D) Hippidion from the Late Pliocene to Early Pleistocene; (E) Equus (Amerhippus) from the Late Pleistocene; (F) Equus (Amerhippus) from the Middle Pleistocene; (G) Equus (Amerhippus) from the plains; (H) Equus (Amerhippus) from the mountain corridor; (I) Hippidion from the plains; and (J) Hippidion from the mountain corridor.

\section{Methods}

Materials

Fossil samples were collected from specimens stored at the following institutions in Argentina: Museo de La Plata, Museo Argentino de Ciencias Naturales "Bernardino Rivadavia" in Buenos Aires and Museo de Ciencias Naturales y Antropológicas "Juan Cornelio Moyano"in Mendoza. Museo de la Escuela Politécnica Nacional of Quito, in Ecuador. The museum specimen number, locality, country, age, skeletal tissue (enamel, bone and dentine) and the altitudinal and latitudinal distribution of each sample are given in Tables 1 and 2. We analyzed 26 samples of Hippidion and 41 carbon and oxygen 
Table 2 Values of $\delta^{18} \mathrm{O}$ and $\delta^{13} \mathrm{C}$ of South American fossil Equus (Amerhippus).

\begin{tabular}{|c|c|c|c|c|c|c|c|c|}
\hline \multirow[t]{2}{*}{ Species name (age) } & \multirow{2}{*}{$\begin{array}{l}\text { Specimen } \\
\text { number }\end{array}$} & \multirow{2}{*}{$\begin{array}{c}\text { Skeletal } \\
\text { tissue }\end{array}$} & \multirow{2}{*}{$\begin{array}{c}\text { Altitude } \\
\text { m.asl. }\end{array}$} & \multirow[t]{2}{*}{ Locality (country) } & \multirow[t]{2}{*}{ Latitude } & \multirow{2}{*}{$\begin{array}{c}d^{13} \mathrm{C} \\
\left(\mathrm{CO}_{3}\right) \\
\% \text { PDB }\end{array}$} & \multirow{2}{*}{$\begin{array}{c}\mathrm{d}^{18} \mathrm{O}\left(\mathrm{PO}_{4}\right) \\
\text { \%o V- } \\
\text { SMOW }\end{array}$} & \multirow{2}{*}{$\begin{array}{c}\mathrm{d}^{18} \mathrm{O}\left(\mathrm{CO}_{3}\right) \\
\% \text { V- } \\
\text { SMOW }\end{array}$} \\
\hline & & & & & & & & \\
\hline Equus sp. (Late Pl)* & UCMP.38100 & $\mathrm{e}$ & 440 & La Venta (Co) & $3 N$ & -0.7 & & 29.9 \\
\hline Equus sp. (Late PI)* & ING 184268 & e & 440 & La Venta (Co) & $3 \mathrm{~N}$ & -2.2 & & 32.4 \\
\hline E. insulatus (Middle PI) & V.543 & $\mathrm{b}$ & 2500 & Rio Chiche (Ec) & 0 & -5.7 & 13.6 & 23.5 \\
\hline E. insulatus (Middle Pl) & V.542 & $\mathrm{t}$ & 2500 & Rio Chiche (Ec) & 0 & -4.8 & 16.7 & 25.1 \\
\hline E. insulatus (Middle PI) & V.542 & $\mathrm{b}$ & 2500 & Rio Chiche (Ec) & 0 & -3.2 & 15.7 & 24.6 \\
\hline E. insulatus (Middle PI) & V.544 & $b$ & 2500 & Rio Chiche (Ec) & 0 & -5.8 & 15.5 & 24.3 \\
\hline E. andium (26 to $19 \mathrm{ka} \mathrm{BP}$ ) & V.455 & $b$ & 2778 & Alangasí (Ec) & 0 & -5.5 & 15.0 & 24.4 \\
\hline E. andium (26 to $19 \mathrm{ka} \mathrm{BP}$ ) & V.430 & $b$ & 2778 & Alangasí (EC) & 0 & -6.9 & 13.1 & 23.3 \\
\hline E. andium (26 to $19 \mathrm{ka} \mathrm{BP}$ ) & V.4014 & $b$ & 2778 & Alangasí (Ec) & 0 & -6.3 & 14.8 & 23.0 \\
\hline E. andium (26 to $19 \mathrm{ka} \mathrm{BP}$ ) & V.2495 & $\mathrm{b}$ & 2778 & Quebrada Colorada (Ec) & $2 S$ & -6.2 & 14.3 & 23.9 \\
\hline E. andium (26 to $19 \mathrm{ka} \mathrm{BP}$ ) & V.2417 & $b$ & 2778 & Quebrada Colorada (Ec) & $2 S$ & -6.7 & 11.3 & 22.0 \\
\hline E. andium (26 to $19 \mathrm{ka} \mathrm{BP}$ ) & V.2163 & $\mathrm{b}$ & 2778 & Quebrada Colorada (Ec) & $2 S$ & -5.8 & 13.2 & 21.7 \\
\hline E. andium (20 to $12 \mathrm{ka} \mathrm{BP}$ ) & V.2161 & $b$ & 2778 & Punín (Ec) & $2 S$ & -9.9 & 14.3 & 25.2 \\
\hline E. andium (20 to $12 \mathrm{ka} \mathrm{BP}$ ) & V.2152 & $b$ & 2778 & Punín (Ec) & $2 S$ & -5.8 & 11.4 & 23.8 \\
\hline E. andium (20 to $12 \mathrm{ka} \mathrm{BP}$ ) & V.465 & $b$ & 2778 & Punín (Ec) & $2 S$ & -6.1 & 14.9 & 23.6 \\
\hline E. santaelenae (12 to 8 ka BP) & V.3037 & $d$ & 0 & La Carolina (Ec) & $2 S$ & 9.2 & 22.1 & 34.9 \\
\hline E. santaelenae (12 to 8 ka BP) & V.3037 & e & 0 & La Carolina (Ec) & $2 S$ & 1.5 & 22.1 & 32.6 \\
\hline E. santaelenae (12 to 8 ka BP) & V.3037 & $b$ & 0 & La Carolina (Ec) & $2 S$ & 6.1 & 21.8 & 33.5 \\
\hline E. santaelenae (12 to 8 ka BP) & V.69 & $b$ & 0 & La Carolina (Ec) & $2 S$ & -1.5 & 21.3 & 32.0 \\
\hline E. santaelenae (12 to $8 \mathrm{ka} \mathrm{BP})^{*}$ & V-3037 & e & 0 & La Carolina (Ec) & $2 S$ & 1.8 & & 32.7 \\
\hline E. santaelenae (12 to $8 \mathrm{ka} \mathrm{BP})^{*}$ & $V-68$ & e & 0 & La Carolina (Ec) & $2 S$ & 5.4 & & 33.6 \\
\hline $\begin{array}{c}\text { E. santaelenae (26 to } 19 \mathrm{ka} \mathrm{BP} \text { ) } \\
*\end{array}$ & F:AM 131869 & e & 0 & Salinas Oil Field (Ec) & $3 S$ & -0.8 & & 32.6 \\
\hline $\begin{array}{c}\text { E. santaelenae (26 to } 19 \mathrm{ka} \mathrm{BP} \text { ) } \\
*\end{array}$ & F:AM 131868 & e & 0 & Salinas Oil Field (Ec) & $3 S$ & 3.0 & & 32.5 \\
\hline E. santaelenae (26 to $19 \mathrm{ka} \mathrm{BP}$ ) & ROM.3471C & e & 85 & Talara Tar Pit (Peru) & $5 S$ & 2.1 & & 27.0 \\
\hline E. neogeus(26 to 19 ka BP)* & uncatalogued & e & 200 & Ourolandia (Br) & 125 & 1.1 & & 29.5 \\
\hline E. neogeus(26 to 19 ka BP)* & uncatalogued & e & 200 & Ourolandia (Br) & 125 & 1.7 & & 30.6 \\
\hline E. neogeus (28 to $10 \mathrm{ka} \mathrm{BP})^{*}$ & UF.uncatalogued & e & 500 & Naupua-3 (Bo) & 215 & 0.2 & & 31.1 \\
\hline E. neogeus(28 to $10 \mathrm{ka} \mathrm{BP})^{*}$ & UF.uncatalogued & e & 500 & Naupua-1 (Bo) & 215 & 0.1 & & 29.8 \\
\hline E. insulatus (44 to $21 \mathrm{ka} \mathrm{BP}$ ) & MACN 1501A & $b$ & 1866 & Tarija (Bo) & 225 & -5.8 & 17.4 & 25.6 \\
\hline E. insulatus (44 to $21 \mathrm{ka} \mathrm{BP}$ ) & MACN 1501B & $\mathrm{t}$ & 1866 & Tarija (Bo) & 225 & -5.0 & 20.9 & 26.2 \\
\hline E. insulatus (44 to $21 \mathrm{ka} \mathrm{BP}$ ) & MACN 1509 & $\mathrm{t}$ & 1866 & Tarija (Bo) & 225 & -8.3 & 20.0 & 28.3 \\
\hline E. insulatus (44 to 21 ka BP)* & UF.uncatalogued & e & 1866 & Tarija (Bo) & 225 & -4.8 & & 25.2 \\
\hline E. insulatus (44 to 21 ka BP)* & UF.uncatalogued & e & 1866 & Tarija (Bo) & 225 & -2.9 & & 24.4 \\
\hline E. insulatus (44 to 21 ka BP)* & UF.uncatalogued & e & 1866 & Tarija (Bo) & 225 & -2.6 & & 25.8 \\
\hline E. insulatus (44 to 21 ka BP)* & UF.uncatalogued & e & 1866 & Tarija (Bo) & 225 & -2.3 & & 26.4 \\
\hline E. insulatus (44 to $21 \mathrm{ka} \mathrm{BP})^{*}$ & UF.90750 & e & 1866 & Tarija (Bo) & 225 & -2.9 & & 26.2 \\
\hline E. insulatus (44 to 21 ka BP)* & UF.90895 & e & 1866 & Tarija (Bo) & 225 & -3.5 & & 23.5 \\
\hline E. insulatus (44 to 21 ka BP)* & UF.90653 & e & 1866 & Tarija (Bo) & 225 & -4.1 & & 26.8 \\
\hline E. insulatus (44 to 21 ka BP)* & UF.90764 & e & 1866 & Tarija (Bo) & 225 & -4.1 & & 24.2 \\
\hline E. insulatus (44 to $21 \mathrm{ka} \mathrm{BP})^{*}$ & UF.91972 & e & 1866 & Tarija (Bo) & 225 & -2.7 & & 24.9 \\
\hline E. neogeus (28 to $10 \mathrm{ka} \mathrm{BP}$ ) & MCNAM-PV-83 & e & 200 & La Banda (Ar) & $28 \mathrm{~S}$ & -1.0 & & 28.0 \\
\hline E. neogeus(Late Pl)* & MLP.52.IX.29-91 & e & 10 & Esperanza, Santa Fé (Ar) & 325 & -0.8 & & 30.8 \\
\hline E. neogeus(Middle PI)* & AMNH.11154 & e & 10 & Buenos Aires (Ar) & $35 S$ & -10.7 & & 30.8 \\
\hline E. neogeus(Middle PI)* & AMNH.11154 & e & 10 & Buenos Aires (Ar) & $35 S$ & -10.3 & & 30.6 \\
\hline E. neogeus(Middle PI)* & MLP.91.VI.5-1 & e & 50 & Magdalena (Ar) & $35 S$ & -10.6 & & 30.3 \\
\hline E. neogeus (28 to $10 \mathrm{ka} \mathrm{BP}$ ) & MACN 11636 & $b$ & 10 & Luján (Ar) & $35 S$ & -11.7 & 21.2 & 30.4 \\
\hline E. neogeus (28 to $10 \mathrm{ka} \mathrm{BP}$ ) & MLP 6-402 & $b$ & 10 & Luján (Ar) & $35 S$ & -11.2 & 20.1 & 30.6 \\
\hline
\end{tabular}


Table 2 Values of $\delta^{18} \mathrm{O}$ and $\delta^{13} \mathrm{C}$ of South American fossil Equus (Amerhippus). (Continued)

\begin{tabular}{|c|c|c|c|c|c|c|c|c|}
\hline E. neogeus (Middle Pl) & $\mathrm{MLP} s / \mathrm{s}$ & $\mathrm{t}$ & 10 & Cant. Vial. Prov.(Ar) & $35 S$ & -7.5 & 21.2 & 30.5 \\
\hline E. neogeus (Middle Pl) & MLP s/s & $\mathrm{b}$ & 10 & Cant. Vial. Prov.(Ar) & $35 S$ & -11.5 & 20.8 & 32.1 \\
\hline E. neogeus (28 to $10 \mathrm{ka} \mathrm{BP}$ ) & MACN 6116 & $\mathrm{t}$ & 50 & Arroyo Tapalqué (Ar) & 385 & -8.5 & 17.3 & 29.8 \\
\hline E. neogeus (28 to $10 \mathrm{ka} \mathrm{BP}$ ) & MACN 6116 & $b$ & 50 & Arroyo Tapalqué (Ar) & 385 & -7.9 & 21.2 & 29.7 \\
\hline E. neogeus (28 to $10 \mathrm{ka} \mathrm{BP}$ ) & MACN 9753 & e & 100 & $\begin{array}{l}\text { Río Quequén Salado } \\
\text { (Ar) }\end{array}$ & 385 & -9.9 & 21.3 & 30.5 \\
\hline E. neogeus (28 to $10 \mathrm{ka} \mathrm{BP}$ ) & MACN 9753 & $d$ & 100 & $\begin{array}{l}\text { Río Quequén Salado } \\
\text { (Ar) }\end{array}$ & 385 & -10.1 & 21.3 & 30.3 \\
\hline E. neogeus (28 to $10 \mathrm{ka} \mathrm{BP}$ ) & MACN 9753 & $\mathrm{~b}$ & 100 & $\begin{array}{l}\text { Río Quequén Salado } \\
\text { (Ar) }\end{array}$ & 385 & -8.0 & 20.4 & 29.8 \\
\hline E. neogeus (28 to $10 \mathrm{ka} \mathrm{BP}$ ) & MACN 9751 & $\mathrm{~b}$ & 100 & $\begin{array}{l}\text { Río Quequén Salado } \\
\text { (Ar) }\end{array}$ & 385 & -7.8 & 21.0 & 30.9 \\
\hline E. neogeus (28 to $10 \mathrm{ka} \mathrm{BP}$ ) & MACN 9751 & $d$ & 100 & $\begin{array}{l}\text { Río Quequén Salado } \\
\text { (Ar) }\end{array}$ & 385 & -8.3 & 22.9 & 31.4 \\
\hline E. neogeus (28 to $10 \mathrm{ka} \mathrm{BP}$ ) & MLP 63-VI-1017 & $b$ & 100 & $\begin{array}{l}\text { Río Quequén Salado } \\
\text { (Ar) }\end{array}$ & 385 & -9.0 & 20.7 & 30.3 \\
\hline E. neogeus(12.8 to $11.5 \mathrm{ka} \mathrm{BP})^{*}$ & MLP.52.X.5-3 & e & 100 & $\begin{array}{l}\text { Rio Quequén Salado } \\
\text { (Ar) }\end{array}$ & 385 & -8.5 & & 30.7 \\
\hline E. neogeus(12.8 to $11.5 \mathrm{ka} \mathrm{BP})^{*}$ & MLP.52.X.5-3 & e & 100 & $\begin{array}{l}\text { Rio Quequén Salado } \\
\text { (Ar) }\end{array}$ & 385 & -7.8 & & 30.9 \\
\hline E. neogeus (28 to $10 \mathrm{ka} \mathrm{BP}$ ) & $\mathrm{MLP} s / \mathrm{s}$ & $\mathrm{t}$ & 10 & P. Hermengo (Ar) & 385 & -7.2 & 20.1 & 29.7 \\
\hline E. neogeus (28 to $10 \mathrm{ka} \mathrm{BP}$ ) & MLP 80-VIII-13-4 & $\mathrm{b}$ & 10 & Paso Otero (Ar) & 385 & -10.7 & 20.1 & 29.8 \\
\hline E. neogeus (28 to $10 \mathrm{ka} \mathrm{BP}$ ) & $\begin{array}{l}\text { MLP 80-VIII-13- } \\
63\end{array}$ & $\mathrm{~b}$ & 10 & Paso Otero (Ar) & 385 & -11.0 & 18.4 & 29.8 \\
\hline E. neogeus (28 to $10 \mathrm{ka} \mathrm{BP}$ ) & MLP.80.VIII.13-93 & e & 10 & Paso Otero (Ar) & 385 & -10.2 & & 31.3 \\
\hline E. neogeus (around $130 \mathrm{ka}$ ) & $\mathrm{MLP} s / \mathrm{s}$ & $\mathrm{t}$ & 10 & Centinela Mar (Ar) & 385 & -10.0 & 19.1 & 30.3 \\
\hline E. neogeus (12.8 to $11.5 \mathrm{ka} \mathrm{BP}$ ) & MACN 14417 & $d$ & 10 & Zanjón Seco (Ar) & 385 & -11.4 & 20.3 & 29.3 \\
\hline E. neogeus (12.8 to $11.5 \mathrm{ka} \mathrm{BP}$ ) & MACN 14417 & $\mathrm{t}$ & 10 & Zanjón Seco (Ar) & 385 & -10.4 & 21.1 & 29.1 \\
\hline E. neogeus (12.8 to $11.5 \mathrm{ka} \mathrm{BP}$ ) & MACN 14417 & e & 10 & Zanjón Seco (Ar) & 385 & -10.5 & 21.2 & 30.7 \\
\hline E. neogeus (12.8 to $11.5 \mathrm{ka} \mathrm{BP}$ ) & MACN 14417 & $\mathrm{~b}$ & 10 & Zanjón Seco (Ar) & 385 & -10.9 & 19.9 & 29.7 \\
\hline
\end{tabular}

Samples with the same "specimen number" correspond to the same individuals. The bones correspond to the mandibular or maxillary remains that contained the teeth that were analyzed. Abbreviations as in Table 1. ${ }^{*}$ taken from MacFadden et al. [25].

isotope composition samples of Equus (Amerhippus). Additional 32 samples values (Table 1 and 2) were taken from MacFadden et al. $[31,33,36]$ and MacFadden and Shockey [34].

\section{Pre-treatment of the samples}

The samples were finely ground in an agate mortar. The chemical pre-treatment of the samples was carried out as described in Koch et al. [58] in order to eliminate secondary carbonate. About 40-50 mg of powdered enamel and bone samples were soaked in $2 \%$ $\mathrm{NaOCl}$ for three days at room temperature to oxidize organic matter. Residues were rinsed and centrifuged five times with de-ionized water, and then treated with buffered $1 \mathrm{M}$ acetic acid for one day to remove diagenetic carbonates. Pre-treatment of the enamel was slightly different because samples were soaked in $2 \%$ $\mathrm{NaOCl}$ for only one day.

\section{Analysis of the samples}

Carbon dioxide was obtained by reacting about 40-50 $\mathrm{mg}$ of the treated powder with $100 \% \mathrm{H}_{3} \mathrm{PO}_{4}$ for five hours at $50^{\circ} \mathrm{C}$. The carbon dioxide was then isolated cryogenically in a vacuum line. Results are reported as $\delta=\left(\left[\mathrm{R}_{\text {sample }} / \mathrm{R}_{\text {standard }}\right]-1\right) \times 1000$, where $\mathrm{R}={ }^{13} \mathrm{C} /{ }^{12} \mathrm{C}$ or ${ }^{18} \mathrm{O} /{ }^{16} \mathrm{O}$, and the standards are PDB for carbon and $\mathrm{V}$-SMOW for oxygen. We have applied the data corrections for calcite from Koch et al. [59] to calculate the magnitude of the oxygen isotopic fractionation between apatite $\mathrm{CO}_{2}$ and $\mathrm{H}_{3} \mathrm{PO}_{4}$ at $50^{\circ} \mathrm{C}$. The analytical variation for repeated analyses was $0,1 \%$ for $\delta^{13} \mathrm{C}$ and $0,2 \%$ for $\delta^{18} \mathrm{O}$. For the analysis of phosphate we followed the chemical treatment procedure described by Tudge [60], which resulted in the precipitation of the phosphate ions in the form of $\mathrm{BiPO}_{4} \cdot \mathrm{CO}_{2}$ was obtained by reacting $\mathrm{BiPO}_{4}$ with $\mathrm{BrF}_{5}$ as described by Longinelli [61]. All the samples were run in duplicate and the reported results are the mean of at least two consistent results. The analytical precision for repeated analyses was 0,2\%o.

We performed both parametric ( $t$-test) and nonparametric (Wilcoxon Signed-Rank) statistical tests to evaluate $\delta^{13} \mathrm{C}$ and $\delta^{18} \mathrm{O}$ differences in Middle and Late Pleistocene populations. SPSS 15.0 software was used for the statistical analysis. 


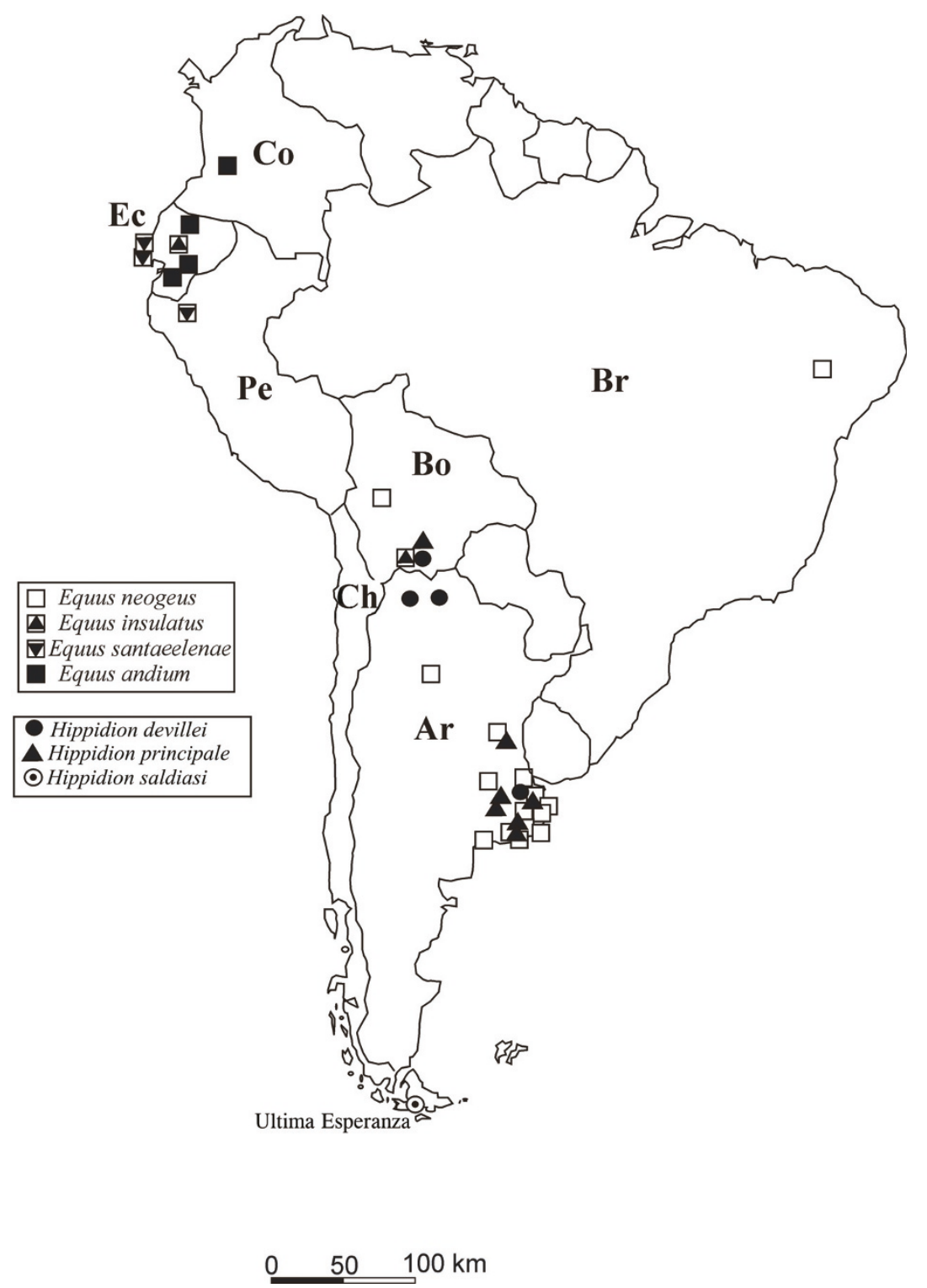

Figure 2 Geographical distribution of analyzed samples. Argentina (Ar), Bolivia (Bo), Brazil (Br), Chile (Ch), and Ecuador (Ec).

\section{Results}

Preservation state of the enamel, dentine and bone in the specimens analyzed

We checked the diagenetic alteration between the different skeletal tissues under the assumption that primary values were similar between different skeletal tissues from one individual. The phosphate oxygen isotope composition is usually considered to be more robust against diagenetic alteration than the carbonate oxygen at least if no bacteria are involved during the alteration processes. We measured both $\delta^{18} \mathrm{O}_{\mathrm{CO} 3}$ and $\delta^{18} \mathrm{O}_{\mathrm{PO} 4}$ values on the same specimens and obtained a regression between both, and compared those with known isotope equilibrium-relationships for biogenic apatite of modern bones and teeth $[40,41]$. If samples fall in the range of modern biogenic apatite this would argue for a preservation of primary $\delta^{18} \mathrm{O}_{\mathrm{CO} 3}$ and $\delta^{18} \mathrm{O}_{\mathrm{PO} 4}$ values, and thus likely also $\delta^{13} \mathrm{C}$ values as they are less easily altered than $\delta^{18} \mathrm{O}$ CO3 values. This was taken as an indicator that even the bone and dentine samples may be reasonably well-preserved and can be interpreted to infer feeding ecology and habitat use of these ancient horses.

Several authors [42-44] suggest a high correlation between these two phases in some European and North American equids. In South America, the equation obtained for Equus(Amerhippus) from Argentina [45] was: $\delta^{18} \mathrm{O}_{\mathrm{CO} 3}=16.74 \delta^{18} \mathrm{O}_{\mathrm{PO} 4}+0.64 ; \mathrm{R}^{2}=0.91$. More recently, Sánchez et al. [8,32] also found that a 
Table 3 Descriptive statistics for the eight groups of South American equids that were compared.

\begin{tabular}{|c|c|c|c|c|c|c|c|c|}
\hline Groups & $n$ & $\begin{array}{c}\text { Mean } \delta^{13} C \\
(\% o) P D B\end{array}$ & $\begin{array}{c}\text { SD } \\
(\% \circ)\end{array}$ & $\begin{array}{c}\text { Range } \\
(\% \circ)\end{array}$ & $n$ & $\begin{array}{c}\text { Mean } \delta^{18} O \\
(\% o) V-S M O W\end{array}$ & $\begin{array}{l}\text { SD } \\
(\% \circ)\end{array}$ & $\begin{array}{c}\text { Range } \\
(\%)\end{array}$ \\
\hline$A$ & 31 & -10.1 & 1.39 & -12.9 to -6.6 & 26 & 28.3 & 2.20 & 24.2 to 31.5 \\
\hline B & 68 & -5.2 & 4.83 & -11.66 to 9.21 & 68 & 28.5 & 3.32 & 21.7 to 34.9 \\
\hline C & 17 & -10.2 & 1.39 & -12.22 to -8.08 & 17 & 29.0 & 2.17 & 24.2 to 31.5 \\
\hline D & 14 & -10.0 & 1.44 & -12.9 to -6.6 & 9 & 27.0 & 1.74 & 25.3 to 29.8 \\
\hline $\mathrm{E}$ & 52 & -5.5 & 5.43 & -11.66 to 9.21 & 50 & 29.4 & 3.17 & 21.7 to 34.9 \\
\hline $\mathrm{F}$ & 16 & -4.3 & 1.61 & -8.31 to -2.3 & 16 & 25.3 & 1.28 & 23.5 to 28.3 \\
\hline G & 43 & -5.3 & 5.93 & -11.66 to 9.21 & 41 & 30.7 & 1.48 & 27 to 34.9 \\
\hline $\mathrm{H}$ & 25 & -5.1 & 1.85 & -9.86 to -2.3 & 25 & 24.6 & 1.51 & 21.7 to 28.3 \\
\hline । & 12 & -9.8 & 1.34 & -12.22 to -6.6 & 8 & 25.8 & 1.30 & 25.8 to 28.7 \\
\hline J & 19 & -10.3 & 1.42 & -8.08 to -12.90 & 17 & 29.7 & 1.00 & 29.7 to 31.5 \\
\hline
\end{tabular}

A: all Hippidion specimens; B: all Equus (Amerhippus) specimens; C: Hippidion from the Late Pleistocene; D: Hippidion from the Late Pliocene to Early Pleistocene; E: Equus (Amerhippus) from the Late Pleistocene; F: Equus (Amerhippus) from the Middle Pleistocene; G: Equus (Amerhippus) from the plains landscape; H: Equus (Amerhippus) from the mountain corridor; I: Hippidion from the plains landscape and J: Hippidion from the mountain corridor. $n$ : number of samples. SD: standard deviation.

significant relationship existed between the $\delta^{18} \mathrm{O}$ results in the carbonate and phosphate apatite phases (enamel, dentine, and bone) when they analyzed the oxygen isotopic composition of gomphotheres from several South American localities. The new data shows that $\delta^{18} \mathrm{O}_{\mathrm{PO}} 4$ and $\delta^{18} \mathrm{O}_{\mathrm{CO} 3}$ are highly correlated, with the latter being about $8.6 \%$ more positive than the former.

We analyzed the $\delta^{18} \mathrm{O}_{\mathrm{PO} 4}$ and $\delta^{18} \mathrm{O}_{\mathrm{CO} 3}$ of the 26 samples for Hippidion and 41 samples for Equus (Amerhippus) in this way. The results of $\delta^{18} \mathrm{O}_{\mathrm{PO} 4}$ versus $\mathrm{V}$-SMOW standard are reported in tables 1 and 2. The analytical variation for repeated analysis was $0.2 \%$. Each pair of $\delta^{18} \mathrm{O}$ values of teeth and bone belonged to the same individual, generally from the jaw or maxilla, the correlation being: $\delta^{18} \mathrm{O}_{\mathrm{PO} 4}=0.9452 \delta^{18} \mathrm{O}_{\mathrm{CO} 3}-10.456$; $\mathrm{R}^{2}=0.80$. We also calculated the correlation between pairs of $\delta^{18} \mathrm{O}_{\mathrm{PO} 4}-\delta^{18} \mathrm{O}_{\mathrm{CO} 3}$ values for the enamel, dentine, and bone, from the same individual. The results are plotted in Figure 3. The correlations between the different $\mathrm{PO}_{4}-\mathrm{CO}_{3}$ pairs are:

Enamel $\delta^{18} \mathrm{O}_{\mathrm{PO} 4}=2.3371 \delta^{18} \mathrm{O}_{\mathrm{CO} 3}-19.095 \mathrm{R}^{2}=0.97$; Dentine $\delta^{18} \mathrm{O}_{\mathrm{PO} 4}=1.2999 \delta^{18} \mathrm{O}_{\mathrm{CO} 3}-3.4034 \mathrm{R}^{2}=0.389$; and Bone $\delta^{18} \mathrm{O}_{\mathrm{PO} 4}=1.1709 \delta^{18} \mathrm{O}_{\mathrm{CO} 3}-6.2038 \mathrm{R}^{2}=0.88$. In the first case it appears that the sample might have been modified by diagenesis because the carbonate results among the three skeletal phases (enamel, dentine, and bone) are different. In fact, the range of variation is $2.6 \%$ in the $\delta^{18} \mathrm{O}_{\mathrm{PO} 4}$ and $5.6 \%$ in the $\delta^{18} \mathrm{O}_{\mathrm{CO} 3}$ for the samples from the same specimen. Results of $\delta^{13} \mathrm{C}$ obtained from the bone are similar to those obtained from the dentine and are, in general, equal or more negative than results obtained from the enamel. We observed the same pattern in the $\delta^{18} \mathrm{O}$ results as we did in the $\delta^{13} \mathrm{C}$ results. The range of variation between the three skeletal phases (enamel, dentine, and bone) was small and we suppose that they have not been significantly altered by diagenesis. For these reasons, we consider these $\delta^{13} \mathrm{C}$ values as representative of each group of horses.

\section{Dietary Partitioning}

The carbon isotopic ratio of Equus (Amerhippus) and Hippidion remains indicate significant ecological differences (Figure 4). The Hippidion samples analyzed here are more homogeneous than the Equus (Amerhippus) samples, with a $\delta^{13} \mathrm{C}$ range between $-12,9$ and $-8,0 \%$ (Table 1 and 2).

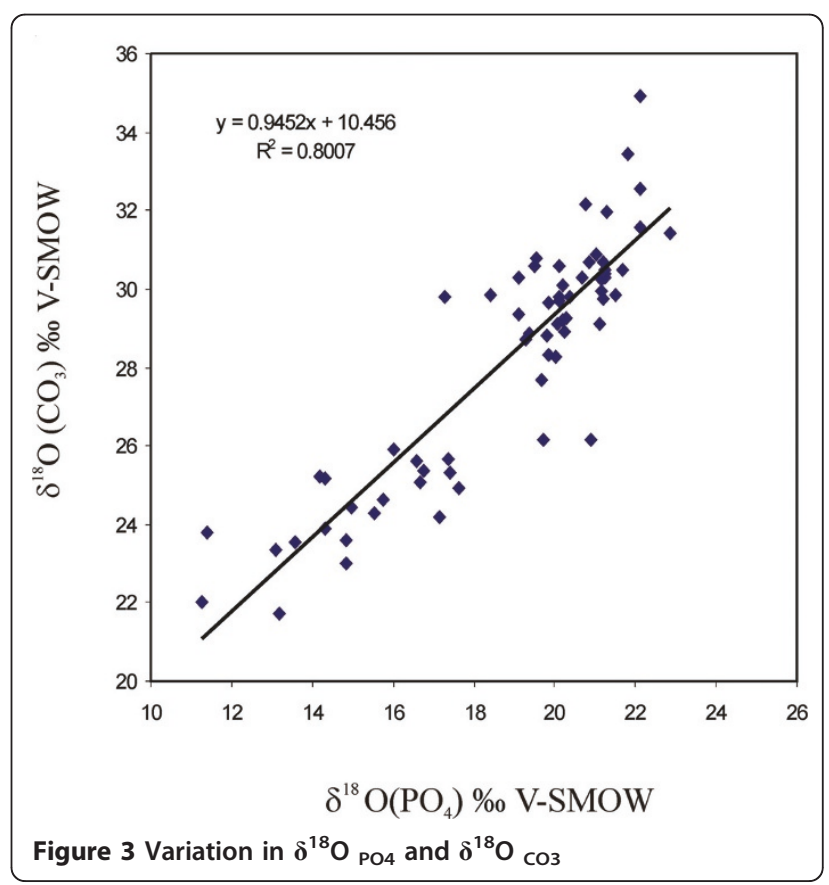




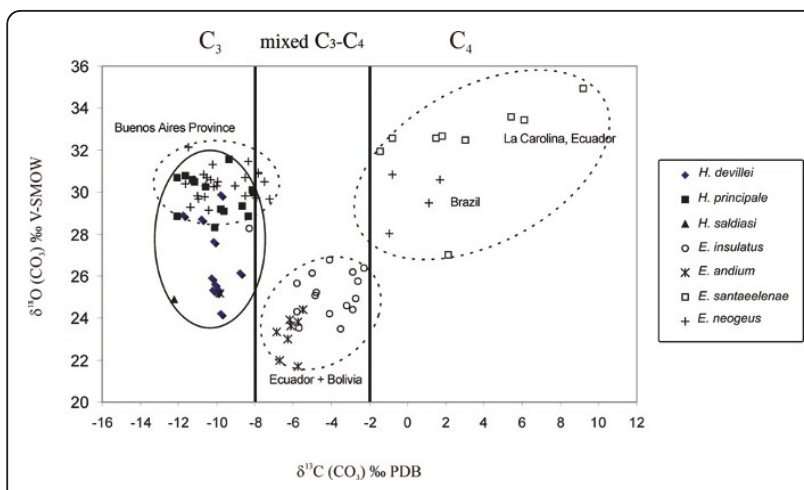

Figure 4 Distribution of $\delta^{18} \mathrm{O}$ versus $\delta^{13} \mathrm{C}$ values of the South American equids.

All the species of Hippidion were almost exclusively $\mathrm{C}_{3}$ feeders but some individuals from Bolivia and Argentina fall at the lower end of the mixed $\mathrm{C}_{3} / \mathrm{C}_{4}$ range. For instance, $H$. principale from the Eastern corridor (at sea level) and $H$. devillei from the Andes corridor yield similar $\delta^{13} \mathrm{C}$ values suggesting that they ate mainly $\mathrm{C}_{3}$ plants. The same pattern of dietary partitioning was obtained when comparisons were made between the same taxa at different latitudes (between $22^{\circ} \mathrm{S}$ and $52^{\circ} \mathrm{S}$ ). From the upper Pliocene $(H$. devillei from Uquía locality) to the lower Pleistocene (H. principale, from the province of Buenos Aires and $H$. devillei from the Tarija locality) the dietary partitioning remains similar. The same pattern in dietary partitioning is observed throughout the Middle to Late Pleistocene (Figure 5) showing a predominance of $\mathrm{C}_{3}$ plants. Also, we did not find differences between $H$. saldiasi from the Ultima Esperanza in southern Patagonia and the other Hippidion species present at different localities across South America.

Equus species have predominantly been grazers, and as such, carbon isotopic values provide evidence of the $\mathrm{C}_{3}$ and $\mathrm{C}_{4}$ grasses. The carbon isotope data indicates that Equus (Amerhippus) shows three different patterns of dietary partitioning. Samples of E. (A.) neogeus from the province of Buenos Aires indicate a preference for $C_{3}$ plants in the diet. The samples from Ecuador and Bolivia $[E$. (A.) andium and E. (A.) insulatus] show a preference for a diet of mixed $\mathrm{C}_{3}-\mathrm{C}_{4}$ plants, while those from La Carolina (sea level of Ecuador), Bolivia, and Brazil are mostly $\mathrm{C}_{4}$ feeders.

As mentioned before, a few outliers (e.g. $\delta^{13} \mathrm{C}$ values of 9,2; 6,1 and 5,4\% from La Carolina) cannot be easily explained. These extremely high $\delta^{13} \mathrm{C}$ values (above $3 \%$ ) cannot be explained by consumption of $\mathrm{C}_{4}$ vegetation, which should impart an upper limit of about $3 \%$. These outliers could be the result from one of several possibilities, such as individuals living in costal peninsula areas of Ecuador during the time in which $\mathrm{C}_{4}$ grasses were
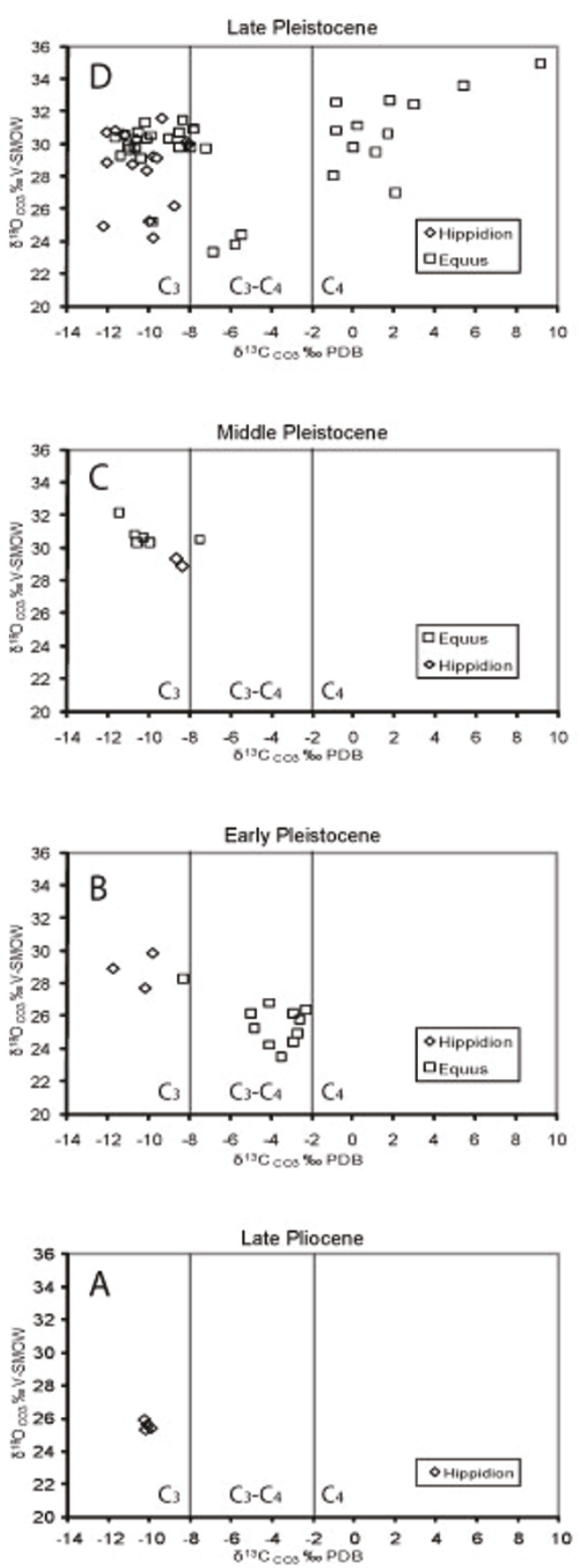

Figure 5 Variation in $\delta^{13} \mathrm{C}$ and $\delta^{18} \mathrm{O}$ with time for South American Hippidion and Equus.

abundant and may have produced $\delta^{13} \mathrm{C}$ values not observed in the modern ecosystem, or the sample presents taphonomic alteration. Specimen number V.3037 has a high variation between dentine, enamel, and bone (9,2; 1,5 and $6,1 \%$ respectively). MacFadden et al [36] obtained a $\delta^{13} \mathrm{C}$ value of $1,8 \%$ for the enamel of the same specimen but obtained 5,4\% for the enamel of 
specimen number v.68 from the same locality. A more definitive explanation for these outliers must await the analysis of additional samples from these regions.

The $\delta^{18} \mathrm{O}{ }_{\mathrm{CO} 3}$ results of the horse remains differ according to altitudinal and latitudinal distribution. There is a clear difference in the $\delta^{18} \mathrm{O}$ values obtained from the populations from the lower plains and those from high elevations. The lowest $\delta^{18} \mathrm{O} \mathrm{CO}_{3}$ values are found in high elevation species from Ecuador and Bolivia [E. (A.) insulatus and E. (A.) andium] and range from 21,3 to $28,3 \%$ with an average of around $25 \%$. The $H$. saldiasi samples from southern Patagonia are also included in this group, their low $\delta^{18} \mathrm{O}$ values being caused by the effects of altitude and latitude. The second group is mostly represented by $E$. (A.) neogeus, $H$. principale and $H$. devillei. These species come from the province of Buenos Aires, Brazil, and Bolivia. The distribution values range from 27,7 to $32,1 \%$ with an average of around $30 \%$. The highest values come from the Carolina Peninsula in Ecuador, with $\delta^{18} \mathrm{O}$ CO3 maximum of $34,9 \%$.

\section{Discussion}

\section{Areas of sympatry}

As might be expected from ecological theory, finer-scale preliminary results from this study suggest feeding and niche differentiation within coexisting horses. Hippidion and Equus (Amerhippus) are sympatric in the same stratigraphic level in two localities: Tarija $\left(22^{\circ} \mathrm{S}\right)$ in Bolivia and the Pampas in Argentina $\left(38^{\circ} \mathrm{S}\right)$. Data from both localities suggest some difference in dietary partitioning. In a previous study, MacFadden and Shockey [34] presented carbon isotopic results from Tarija herbivores that, based on dental morphology, span the spectrum from presumed browsers (e.g., tapirs) to presumed grazers (e.g., horses) coexisting in the same localities. They suggested than the horses clearly occupied different dietary niches and can be separated using the carbon isotopes and hypsodonty index. Hippidion is the least hypsodont taxon and has the most negative mean $\delta^{13} \mathrm{C}$ value, whereas the relatively hypsodont Equus has the most positive mean $\delta^{13} \mathrm{C}$ value. As has been shown in another article [36], Equus is usually among the most grazing adapted mammalian herbivore in Pleistocene terrestrial ecosystems. This position in the herbivore community is similar at Tarija, whereas Hippidion are more adapted to the browsing end of the spectrum and Equus are primarily $\mathrm{C}_{4}$ grazers based on their carbon isotopic signature.

Our data suggests that the range of $\delta^{13} \mathrm{C}$ values for $H$. devillei and $H$. principale from Tarija falls in the low end of the mixed $C_{3} / C_{4}$ range $(-10,8$ to $-6,6 \%$ ), whereas E. (A.) insulatus falls in the higher end $(-8,3$ to $-2,3 \%$ ). There is some overlap with at least the two values of
$-8,3$ and $-6,6 \%$ indicating some differences in isotopic niche, with $H$. devillei consuming less grass than $E$. (A.) insulatus at this place and time [36].

In the data from Arroyo Tapalque $\left(38^{\circ} \mathrm{S}\right)$, one of the localities in the Pampas, the range of $\delta^{13} \mathrm{C}$ values for $H$. principale $(-11,6$ to $-9,3 \%$ o) and $E$. (A.) neogeus $(-8,5$ to $-7,9 \%$ ) do not overlap, but both are close that they suggest the same pattern of dietary partitioning as in Tarija.

If we look at the morphology, these taxa are very different. Several previous papers based on cranial and limb morphology associate these differences with browsing and grazing diet preference [e.g. [46]]. In general, the teeth of Equus (Amerhippus) are more hypsodont than Hippidion, and the enamel patterns are more complicated in Equus (Amerhippus).

Another difference between sympatric species is body sizes. For instance, $H$. principale and $E$. (A.) neogeus are sympatric in the Pampas in Argentina. Both have a large body size, adapted to open habitat, but they differ in body mass (460 kg and $378 \mathrm{~kg}$, respectively) [47]. The skulls of $E$. (A.) neogeus are big and show an enlarged preorbital and nasal region. The limb bones are large and robust, but more slender than in the other South American Equus species [3,4]. On the other hand, $H$. principale has a retracted nasal notch might signify some sort of proboscis. The skeleton is large and bulky, and the extremities are robust, mainly the metapodials and phalanges. It is the largest and strongest of the South American hippidiforms. These characteristics are classically associated with dietary and habitat preferences. The morphology indicated that $H$. principale may have been a browser but was able to live in open grasslands and that $E$. (A.) neogeus is the most hypsodont horse, and has the relatively straight muzzle characteristic of grazing horses [46].

\section{The effect of latitude}

Some of the most fundamental patterns in global biogeography are those that are structured by the latitudinal gradients that extend from pole to equator (Figure 6). The proportion of $\mathrm{C}_{3}$ to $\mathrm{C}_{4}$ grasses in most modern ecosystems rises with increasing latitude. $\mathrm{C}_{3}$ grasses are predominant $(>90 \%)$ in high-latitude steppes and prairies, whereas $\mathrm{C}_{4}$ grasses are predominant $(>70$ $90 \%$ ) in most low-elevation, and equatorial grasslands. The transition between $\mathrm{C}_{3}$ and $\mathrm{C}_{4}$ dominance in grasslands occurs at about $40-45^{\circ}$ latitude in the Northern Hemisphere [48-50]. Exceptions to this general rule include grasses at high-elevations or in climates with cool-growing seasons (e.g. the Mediterranean basin), where the grasses are predominantly $\mathrm{C}_{3}$ regardless of latitude [50-52], and the occasional $\mathrm{C}_{4}$ grass species that are found in Arctic regions [53]. 


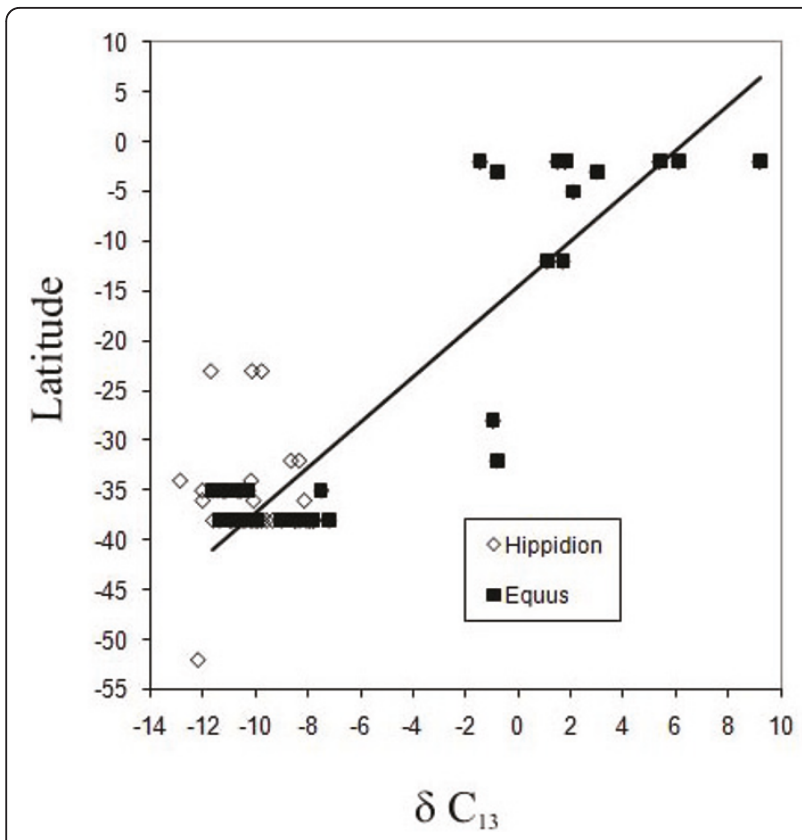

Figure 6 Latitudinal distribution of $\delta^{13} \mathrm{C}$ values for the two species of South American equids.

MacFadden et al. [36] used the Pleistocene distribution of Equus (Amerhippus) in the Americas to present a general $\delta^{13} \mathrm{C}$ gradient that seems to be symmetrical on either side of the Equator. They found that the isotopic transition between a full $C_{4}$ signal and full $C_{3}$ signal is observed at about $45^{\circ} \mathrm{N}$ in the northern hemisphere. Although there are considerably fewer data points in the southern hemisphere they [36] have found a signal of exclusively $\mathrm{C}_{3}$ feeders at around $35^{\circ} \mathrm{S}$ (province of Buenos Aires). A similar pattern in the Southern Hemisphere was found by Sánchez et al. [32] in the distribution of gomphotheres in South America. Samples of gomphotheres from the province of Buenos Aires, at around $39^{\circ} \mathrm{S}$ latitude show a mean $\delta^{13} \mathrm{C}$ value of $-10,8 \%$, while samples from Chile (from several localities around $35^{\circ}$ to $41^{\circ} \mathrm{S}$ ) show a mean $\delta^{13} \mathrm{C}$ value of $-12,3 \%$. This fact would confirm the existence of a latitudinal gradient for the Southern Hemisphere, and places the transition between a full $\mathrm{C}_{3}$ signal and mixed $\mathrm{C}_{3} / \mathrm{C}_{4}$ signal around $35^{\circ}$ to $41^{\circ} \mathrm{S}$.

The new data for the genus Equus (Amerhippus) analyzed in this paper are in agreement with the $\delta^{13} \mathrm{C}$ latitudinal pattern postulated by MacFadden et al. [36], while data for Hippidion also seem to follow a clear pattern. Samples of Hippidion show a boundary between an exclusively $\mathrm{C}_{3}$ to a mixed $\mathrm{C}_{3} / \mathrm{C}_{4}$ diet at Tarija $\left(22^{\circ} \mathrm{S}\right)$, but in this case there is an effect of altitude combined with latitude. At the highest latitude specimens from Patagonia $\left(52^{\circ} \mathrm{S}\right)$, the mean value is $-12.2 \%$. The middle latitude samples, from the province of Buenos Aires $\left(34^{\circ} \mathrm{S}\right)$, show $\delta^{13} \mathrm{C}$ values that range between $-12,9$ and $-8,1 \%$, while the lowest latitude specimens, from Tarija $\left(22^{\circ} \mathrm{S}\right)$, show $\delta^{13} \mathrm{C}$ values that range between $-6,6$ to $-0,8 \%$.

\section{Altitudinal gradient}

There are also significant differences between the $\delta^{18} \mathrm{O}$ $\mathrm{CO} 3$ values for the two genera, even when the range of $\delta^{18} \mathrm{O}$ values for high altitude and equatorial samples are taken into account (Table 4). This demonstrates the effects of an altitudinal gradient. The Hippidion specimens from the Andes corridor (Bolivia and northern Argentina) and the Equus (Amerhippus) specimens from Ecuador and Bolivia show the lowest values (between 21,7 and 28,3\%o). On the other hand, samples from around $500 \mathrm{~m}$ of altitude (Bolivia, Ecuador, Brazil, Peru, and Argentina) present values that correspond with more temperate conditions $(27,7$ to $32,1 \%$ ). The effects of low altitude and latitude on $\delta^{18} \mathrm{O} \mathrm{CO}_{3}$ may also explain the higher value obtained for the samples from La Carolina, Ecuador (sea level, latitude $2^{\circ} \mathrm{S}$ ), where samples showed $\delta^{18} \mathrm{O}$ values ranging from 32 to $34,9 \%$.

We calculated a regression of $\delta^{18} \mathrm{O}_{\mathrm{PO} 4}$ values with altitude to quantify the effects of altitude. Bryant et al. [44] suggest a high correlation between $\delta^{18} \mathrm{O}_{\mathrm{PO} 4}$ and $\delta^{18} \mathrm{O}{ }_{\mathrm{CO} 3}$ in Miocene North American equids. We found a good correlation between $\delta^{18} \mathrm{O}_{\mathrm{PO} 4}$ values and altitude. The equation obtained was: $\delta^{18} \mathrm{O}_{\mathrm{PO} 4}=-0.0016$ altitude $+20.47\left(R^{2}=0.63\right)$. We obtained an altitudinal gradient of $-0.16 \delta$ unit/100 meters.

An important point concerns altitudinal gradients. It seems that the horses living at high altitudes, 1866 up to $2780 \mathrm{~m}$ above sea level, and at low to middle latitude

Table 4 Results of parametric (t - test) and nonparametric (Wilcoxon Signed-Rank) tests.

\begin{tabular}{cccc}
\hline & & $\boldsymbol{t}$-test & Nonparametric \\
Variable & Comparison groups & $\boldsymbol{p}$ & $\boldsymbol{p}$ \\
\hline$\delta^{13} \mathrm{C}$ & A vs. B & $\mathbf{3 , 6 E}-10$ & $\mathbf{1 , 1 7 E - 0 6}$ \\
$\delta^{13} \mathrm{C}$ & C vs. D & 0,97 & 0,73 \\
$\delta^{13} \mathrm{C}$ & E vs F & 0,12 & 0,33 \\
$\delta^{13} \mathrm{C}$ & G vs. H & 0,15 & 0,15 \\
$\delta^{13} \mathrm{C}$ & C vs. E & $\mathbf{2 , 2 E - 0 5}$ & $\mathbf{2 , 9 E - 0 4}$ \\
$\delta^{13} \mathrm{C}$ & D vs. F & $\mathbf{3 , 1 E}-\mathbf{0 7}$ & $\mathbf{9 , 8 E}-\mathbf{0 4}$ \\
$\delta^{13} \mathrm{C}$ & I vs. J & 0,17 & $\mathbf{0 , 0 4}$ \\
$\delta^{18} \mathrm{O}$ & A vs. B & 0,85 & 0,93 \\
$\delta^{18} \mathrm{O}$ & C vs. D & $\mathbf{0 , 0 1}$ & $\mathbf{0 , 0 2}$ \\
$\delta^{18} \mathrm{O}$ & E vs F & 0,08 & 0,18 \\
$\delta^{18} \mathrm{O}$ & G vs. H & $\mathbf{1 , 4 E - 1 2}$ & $\mathbf{1 , 2 E}-\mathbf{0 5}$ \\
$\delta^{18} \mathrm{O}$ & C vs. E & 0,52 & 0,46 \\
$\delta^{18} \mathrm{O}$ & D vs. F & 0,08 & 0,09 \\
$\delta^{18} \mathrm{O}$ & I vs. J & $\mathbf{0 , 0 1}$ & $\mathbf{0 , 0 3}$ \\
\hline
\end{tabular}

Results of tests performed on twelve possible paired comparisons between two genera of South American equids. The definition of groups is the same as for table 3. $p$ : significance level. $p<0.05$ in bold. 
$\left(2^{\circ}\right.$ to $22^{\circ} \mathrm{S}$ ) still have a $\mathrm{C}_{4}$ component in their diet. This is not surprising at all given the distribution of modern $\mathrm{C}_{4}$ plants in the central Andes. At present, three $\mathrm{C}_{4}$ Amaranthaceae species occur at high elevations $(>4000$ m) where $C_{4}$ plants are rarely observed and the altitude record reported for any confirmed $\mathrm{C}_{4}$ species worldwide is $4800 \mathrm{~m}$ for the grass Muhlenbergia peruviana [54]. However, this is not true for our specimens from 4000 $\mathrm{m}$, which have a pure $\mathrm{C}_{3}$ diet. In this central Andean region, a clear altitudinal vegetation gradient is present. Subparamo (2000-3000 m) presents mosaics where shrubs and small trees which alternate with grasslands; and Paramo proper (3000 - $4100 \mathrm{~m}$ ), is dominated by grasslands and shows patches of woody species which occur only in sheltered locations and along water streams. This altitudinal vegetation gradient changed during the Pleistocene. The treeless vegetation above the upper forest line was most widespread during glacial times, whereas it was limited to small areas on mountain tops during interglacial times [55]. The fossil pollen records show that such oscillations in patterns of plant distribution were repeated many times during the Pleistocene Ice Ages [56]. During the Last Glacial Maximum, when atmospheric $p \mathrm{CO}_{2}$ was reduced by some $50 \%, \mathrm{C}_{4}$ plants dominated the Paramo vegetation, while only the highest mountain tops were covered by $\mathrm{C}_{3}$ grasses because of the low temperatures. Such small patches of $\mathrm{C}_{4}$-rich vegetation are probably relicts from the last ice age during which paramo vegetation was mainly composed of small tussocks and tufts of $\mathrm{C}_{4}$ grasses [57].

The change in altitudinal vegetation gradients during the Pleistocene is one of several possibilities to explain the $\mathrm{C}_{4}$ dietary component in horses living at high altitudes. Another alternative explanation might be that the horses partially fed at lower altitudes.

\section{Conclusions}

Based on modern analogues, Pleistocene horses are inferred to be grazers but none of the grazing horses were interpreted as consumers of only $\mathrm{C}_{4}$ grasses. Our data shows that Equus (Amerhippus) had three different patterns of dietary partitioning. E. (A.) neogeus from the province Buenos Aires indicates a preference for $C_{3}$ plants. E. (A.) andium from Ecuador and E. (A.) insulatus from Bolivia show a preference in a mixed diet of $\mathrm{C}_{3}-\mathrm{C}_{4}$ plants, while $E$. (A.) santaeelenae from La Carolina (sea level of Ecuador) and Brazil are mostly $\mathrm{C}_{4}$ feeders. These results confirm that ancient feeding ecology cannot always be inferred from dental morphology.

The record from South America suggests that Hippidion is in general a higher latitude taxon than Equus (Amerhippus). The highest latitude occurrence of Hippidion appears to be in southern Bolivia, in contrary to Equus (Amerhippus) where the occurrences are further north, and alone goes a long way in explaining the isotopic differences.

The data for Hippidion indicates a preference for $\mathrm{C}_{3}$ plants and mixed $\mathrm{C}_{3}-\mathrm{C}_{4}$ plants, but most of this data came from high altitude or latitude specimens. One possible, but unconfirmed explanation is that Hippidion were living in a " $\mathrm{C}_{4}$ World" and were browsers as indicated by their morphology, but more southern individuals were living at latitudes high enough to support $C_{3}$ and $C_{4}$ grasses.

The current study demonstrates the utility of using wide-ranging fossil mammals to explore latitudinal gradients and patterns of $\mathrm{C}_{3} / \mathrm{C}_{4}$ grass distribution and continental palaeotemperature during the Pleistocene. The carbon isotope composition of horses decreased as latitude increased. In Equus (Amerhippus) we found a change in signal between a mixed $C_{3} / C_{4}$ diet and a pure $\mathrm{C}_{4}$ diet around $32^{\circ} \mathrm{S}$ and a boundary between mixed diet and exclusively $\mathrm{C}_{3}$ signals at $35^{\circ} \mathrm{S}$.

We also found that the horses living at high altitudes and at low to middle latitudes still have a $\mathrm{C}_{4}$ component in their diet, except for those specimens living at $4000 \mathrm{~m}$, which have a pure $C_{3}$ diet. The change in altitudinal vegetation gradients during the Pleistocene is one of several possibilities to explain the $\mathrm{C}_{4}$ dietary component in horses that lived at high altitudes. Another alternative explanation implies that the horses fed partially at lower altitudes.

\section{Abbreviations}

(MLP): Museo de La Plata; (MACN): Museo Argentino de Ciencias Naturales "Bernardino Rivadavia", Buenos Aires; and (NCNAM): Museo de Ciencias Naturales y Antropológicas "Juan Cornelio Moyano", Mendoza, in Argentina; and (MEPN): Museo de la Escuela Politécnica Nacional of Quito, in Ecuador

\section{Acknowledgements}

We wish to thank the curators of the Museo de La Plata and the Museo Argentino de Ciencias Naturales "Bernardino Rivadavia", Argentina; the Museo de la Escuela Politécnica Nacional de Quito, Ecuador, and specially S. López, who was responsible for the samples; the isotope geochemistry laboratory at the Università di Trieste, Centrum voor Isotopenonderzoek, Groningen and Servicio de Isótopos estables of the Salamanca University. The manuscript was greatly improved by thoughtful review from three anonymous referees. Dan Rafuse revised the English text. Funding was provided by a Projects CGL2007-60790/BTE and CGL2010-19116/BOS from the Dirección General de Investigación Científica y Técnica of Spain and Projects AECID A/023681/09 and A/030111/10; grants from the Universidad Nacional del Centro de la provincial de Buenos Aires (http://www.unicen. edu.ar) and the Project ANPCYT (http://www.agencia.gov.ar) PICT 07-01563, Argentina. The funders had no role in study design, data collection and analysis, decision to publish, or preparation of the manuscript.

\section{Author details}

${ }^{1}$ INCUAPA, Universidad Nacional del Centro. Del Valle 5737. B7400JWI Olavarría, Argentina. ${ }^{2}$ Museo Nacional de Ciencias Naturales, CSIC. José Gutiérrez Abascal, 2. 28006-Madrid, Spain

\section{Authors' contributions}

Conceived and designed the experiments: JLP MTA. Performed the experiments: BS. Analyzed the data: BS. Wrote the paper: JLP BS. Intellectual support and editorial input: JLP MTA. All authors read and approved the final manuscript. 
Received: 14 April 2010 Accepted: 14 June 2011

Published: 14 June 2011

\section{References}

1. Alberdi MT: La familia Equidae, Gray, 1821 (Perissodactyla, Mammalia) en el Pleistoceno de Sudamérica. In IV Congreso Latinoamericano de Paleontología. Volume 1. Santa Cruz de la Sierra, Bolivia; 1987:484-499.

2. Alberdi MT, Prado JL: Review of the genus Hippidion Owen, 1869 (Mammalia; Perissodactyla) from the Pleistocene of South America. Zoological Journal of the Linnean Society 1993, 108:1-22.

3. Prado JL, Alberdi MT: A quantitative review of the horse Equus from South America. Paleontology 1994, 37:459-481.

4. Alberdi MT, Prado JL: El registro de Hippidion Owen, 1869 y Equus (Amerhippus) Hoffstetter, 1950 (Mammalia, Perissodactyla) en América del Sur. Ameghiniana 1992, 29:265-284

5. MacFaddden BJ: Fossil Horses. Systematics, Paleobiology, and Evolution of the Family Equidae Cambridge University Press; 1992.

6. MacFadden BJ, Cerling TE: Mammalian herbivore communities, ancient feeding ecology, and carbon isotopes: a 10 million year sequence from the Neogene of Florida. Journal of Vertebrate Paleontology 1996, 16:103-115.

7. Cerling TE, Harris JM, MacFadden BJ, Leakey MG, Quade J, Eisenmann V, Ehleringer JR: Global vegetation change through the Miocene/Pliocene boundary. Nature 1997, 389:153-158.

8. Sánchez B, Prado JL, Alberdi MT: Ancient feeding ecology and extinction of Pleistocene Horses from Pampean Region (Argentina). Ameghiniana 2006, 43:427-436.

9. Bryant JD, Luz B, Froelich PN: Oxygen isotopic composition of fossil horse tooth phosphate as a recorder of continental paleoclimate. Palaeogeography Palaeoclimatology Palaeoecology 1994, 107:303-316.

10. Wang Y, Cerling TE, MacFadden BJ: Fossil horses and carbon isotopes: new evidence for Cenozoic dietary, habitat, and ecosystem changes in North America. Palaeogeography Palaeoclimatology Palaeoecology 1994 107:269-279

11. Cerling TE, Harris JM, MacFadden BJ: Carbon isotopes, diets of North American equids, and the evolution of North American C4 grasslands. In Stable Isotopes. Edited by: Griffiths H. BIOS Scientific Publishers Ldt, Oxford; 1998:363-379.

12. MacFadden B, Solounias N, Cerling TE: Ancient diets, ecology, and extinction of 5-million-year-old horses from Florida. Science 1999, 283:824-827.

13. Passey BH, Cerling TE, Perkins ME, Voorhies MR, Harris JM, Tucker ST: Environmental change in the great plains: An isotopic record from fossil horses. The Journal of Geology 2002, 110:123-140.

14. Domingo L, Grimes ST, Domingo MS, Alberdi MT: Paleoenvironmental conditions in the Spanish Miocene-Pliocene boundary: isotopic analyses of Hipparion dental enamel. Naturwissenschaften 2009.

15. Tütken T, Vennemann TW: Stable isotope ecology of Miocene mammals of Sandelzhausen, Germany. Paläontologische Zeitschrift 2009, 83:207-226.

16. Van Dam JA, Reichart GJ: Oxygen and carbon isotope signatures in late Neogene horse teeth from Spain and application as temperature and seasonality proxies. Palaeogeography, Palaeoclimatology, Palaeoecology 2009, 274:64-81.

17. Feranec RS, Hadly EA, Paytan A: Stable isotopes reveal seasonal competition for resources between late Pleistocene bison (Bison) and horse (Equus) from Rancho La Brea, southern California. Palaeogeography, Palaeoclimatology, Palaeoecology 2009, 271:153-160.

18. Smith $\mathrm{BN}$, Epstein S: Two categories of ${ }^{13} \mathrm{C} /{ }^{12} \mathrm{C}$ ratios for higher plants. Plant Physiology 1971, 47:380-384

19. Vogel JC, Fuls A, Ellis RP: The geographical distribution of kranz grasses in South Africa. South African Journal of Science 1978, 74:209-215.

20. Ehleringer JR, Field CB, Lin ZF, Kuo CY: Leaf carbon isotope and mineral composition in subtropical plants along an irradiance cline. Oecologia 1986, 70:520-526.

21. Ehleringer JR, Sage RF, Flanagan LB, Pearcy RW: Climatic change and evolution of C4 photosynthesis. Trends in Ecology and Evolution 1991 6:95-99.

22. Cerling TE, Wang $Y$, Quade J: Expansion of C4 ecosystems as an indicator of global ecological change in the Late Miocene. Nature 1993, 361:344-45.
23. Cerling TE, Harris JM: Carbon isotope fractionation between diet and bioapatite in ungulate mammals and implications for ecological and paleoecological studies. Oecologia 1999, 120:347-363.

24. Passey BH, Cerling TE, Schuster GT, Robinson TF, Roeder BL, Ehleringer JR: Inverse methods for estimating primary input signals from time-averaged isotope profiles. Geochim Cosmochim Acta 2005, 69:4101-4116.

25. Lee-Thorp JA, Van der Merwe NJ: Carbon isotope analysis of fossil bones apatite. South African Journal of Science 1987, 83:712-715.

26. Quade J, Cerling TE, Barry JC, Morgan ME, Pillbeam DR, Chivas AR, LeeThorp JA, van der Merwe : A 16-Ma record of paleodiet using carbon and oxygen isotopes in fossil teeth from Pakistan. Chemical Geology (Isotope Geoscience Section) 1992, 94:183-192.

27. Latorre C, Quade J, McIntosh WC: The expansion of C4 grasses and global change in the late Miocene: Stable isotope evidence from the Americas. Earth and Planetary Science Letters 1997, 146:83-96.

28. MacFadden BJ: Middle Pleistocene climate change recorded in fossil mammal teeth from Tarija, Bolivia, and upper limit of the Ensenadan Land-Mammal Age. Quaternary Research 2000, 54:121-131.

29. MacFadden BJ: Diet and habitat of toxodont megaherbivores (Mammalia, Notoungulata) from the late Quaternary of South and Central America. Quaternary Research 2005, 64:113-124.

30. MacFadden BJ, Higgins P: Ancient ecology of 15-million-year-old browsing mammals within $\mathrm{C} 3$ plant communities from Panamá. Oecologia 2004, 140:169-182.

31. MacFadden BJ, Cerling TE, Prado JL: Cenozoic terrestrial ecosystem evolution in Argentina: evidence from carbon isotopes of fossil mammal teeth. Palaios 1996, 11:319-327.

32. Sánchez B, Prado JL, Alberdi MT: Feeding ecology, dispersal, and extinction of South American Pleistocene gomphotheres (Gomphotheriidae, Proboscidea). Paleobiology 2004, 30:146-161.

33. MacFadden BJ, Wang Y, Cerling TE, Anaya F: South American fossil mammals and carbon isotopes: A 25 million - year sequence from the Bolivian Andes. Palaeogeography, Palaeoclimatology, Palaeoecology 1994, 107:257-268

34. MacFadden BJ, Shockey BJ: Ancient feeding ecology and niche differentiation of Pleistocene mammalian herbivores from Tarija, Bolivia: morphological and isotopic evidence. Paleobiology 1997, 23:77-100.

35. MacFadden BJ: Cenozoic mammalian herbivores from the Americas: reconstructing ancient diets and terrestrial communities. Annual Reviews Ecology and Systematic 2000, 31:33-59.

36. MacFadden BJ, Cerling TE, Harris JM, Prado JL: Ancient latitudinal gradients of $C_{3} / C_{4}$ grasses interpreted from stable isotopes of New World Pleistocene horse (Equus) teeth. Global Ecology and Biogeography 1999, 8:137-149.

37. MacFadden BJ: Tale of two rhinos: isotopic ecology, paleodiet, and niche differentiation of Aphelops and Teleoceras from the Florida Neogene. Paleobiology 1998, 24:274-286.

38. Alberdi MT, Menegaz AN, Prado JL: Formas terminales de Hippidion (Mammalia, Perissodactyla) de los yacimientos del Pleistoceno tardío Holoceno de la Patagonia (Argentina y Chile). Estudios Geológicos 1997, 43:107-115.

39. Alberdi MT, Prado JL, Miotti L: Hippidion saldiasi Roth, 1899 (Mammalia, Perissodactyla) at the Piedra Museo Site (Patagonia): their implication for the regional economy and environmental reconstruction. Journal of Archaeological Science 2001, 28:411-419.

40. lacumin P, Bocherens $H$, Mariotti A, Longinelli A: Oxygen isotope analyses of coexisting carbonate and phosphate in biogenic apatite: a way to monitor diagenetic alteration of bone phosphate? Earth and Planetary Science Letters 1996, 142:1-6.

41. Martin C, Bentaleb I, Kaandorp R, lacumin P, Chatri K: Intra-tooth study of modern rhinoceros enamel $\delta^{18} \mathrm{O}$ : Is the difference between phosphate and carbonate $\delta^{18} \mathrm{O}$ a sound diagenetic test? Palaeogeography, Palaeoclimatology, Palaeoecology 2008, 266:183-189.

42. Sánchez-Chillón B, Alberdi MT, Leone G, Bonadonna FP, Stenni B, Longinelli A: Oxygen isotopic composition of fossil equid tooth and bone phosphate: an archive of difficult interpretation. Palaeogeography, Palaeoclimatology, Palaeoecology 1994, 107:317-328.

43. Delgado A, lacumin P, Stenni B, Sánchez B, Longinelli A: Oxygen isotope variations of phosphate in mammalian bone and tooth enamel. Geochimica et Cosmochimica Acta 1995, 59:4299-4305. 
44. Bryant JD, Froelich PN, Showers WJ, Genna BJ: Biologic and climatic signals in the oxygen isotopic composition of Eocene-Oligocene equid enamel phosphate. Palaeogeography, Palaeoclimatology, Palaeoecology 1996, 126:75-89.

45. Sánchez-Chillón B, Alberdi MT: Taphonomic modification of oxygen isotopic composition in some South American Quaternary mammal remains. In // Reunión de Tafonomía y Fosilización Edited by: Meléndez G, Blasco MF, Pérez I 1996, 353-356.

46. Alberdi MT, Prado JL: Caballos fósiles de América del Sur. Una historia de tres millones de años INCUAPA Serie Monográfica; 2004.

47. Alberdi MT, Ortiz Jaureguizar O, Prado JL: Patterns of body size changes in fossil and living Equini (Perissodacyla). Biological Journal of the Linnean Society 1995, 54:349-379.

48. Ehleringer JR, Cerling TE, Helliker BK: $\mathrm{C}_{4}$ photosynthesis, atmospheric $\mathrm{CO}_{2}$, and climate. Oecologia 1997, 112:285-299.

49. Epstein HE, Lauenroth WK, Burke IC, Coffin DP: Productivity patterns of $C_{3}$ and $C_{4}$ functional types in the U.S. Great Plains. Ecology 1997, 78:722-731.

50. Tieszen $L L$, Hein D, Qvortrup SA, Troughton HJ, Imbamba SK: Use of $\delta^{13} \mathrm{C}$ values to determine vegetation selectivity in East African herbivores. Oecologia 1979, 37:351-359.

51. Cavagnaro JB: Distribution of C3 and C4 grasses at different altitudes in a temperate arid region of Argentina. Oecologia 1988, 76:273-277.

52. Cabido M, Ateca N, Astegiano ME, Anton ME: Distribution of C3 and C4 grasses along an altitudinal gradient in northern Argentina. Journal of Biogeography 1997, 24:197-204.

53. Schwarz AG, Redman RE: C4 grasses from the boreal forest region of Northwestern Canada. Canadian Journal of Botany 1988, 66:2424-2430.

54. Ruthsatz B, Hofmann U: Die Verbreitung von C4-Pflanzen in den semiariden Anden NW-Argentiniens mit einem Beitrag zur Blattanatomie ausgewahlter Beispiele. Phytocoenologia 1984, 12:219-249.

55. Van der Hammen T: The Pleistocene changes of vegetation and climate in tropical South America. Journal of Biogeography 1974, 1:3-26.

56. Boom AM, Marchant $\mathrm{R}$, Hooghiemstra $\mathrm{H}$, Sinninghe Damsté JS: $\mathrm{CO}_{2}$ - and temperature-controlled altitudinal shifts of C4- and C3-dominated grasslands allow reconstruction of palaeoatmosphere $p \mathrm{CO} 2$. Palaeogeography, Palaeoclimatology, Palaeoecology 2002, 177:151-168.

57. Hooghiemstra H, Van der Hammen T: Quaternary Ice-Age dynamics in the Colombian Andes: developing an understanding of our legacy. Phil. Trans. R. Soc. Lond 2004, 359:173-181.

58. Koch PL, Tuross N, Fogel ML: The effects of sample treatment and diagenesis on the isotopic integrity of carbon in biogenic hydroxylapatite. Journal of Archaeological Science 1997, 24:417-429.

59. Koch PL, Fisher DC, Dettman D: Oxygen isotope variation in the tusks of extinct proboscideans: a measure of season of death and seasonality. Geology 1989, 17:515-519.

60. Tudge AP: A method of analysis of oxygen isotopes in orthophosphate: its use in the measurement of paleotemperatures. Geochimica et Cosmochimica Acta 1960, 18:81-93.

61. Longinelli A: Oxygen isotopic composition of orthophosphate from shells of living marine organisms. Nature 1965, 207:716-718.

doi:10.1186/1472-6785-11-15

Cite this article as: Prado et al:: Ancient feeding ecology inferred from stable isotopic evidence from fossil horses in South America over the past 3 Ma. BMC Ecology 2011 11:15.

\section{Submit your next manuscript to BioMed Central and take full advantage of:}

- Convenient online submission

- Thorough peer review

- No space constraints or color figure charges

- Immediate publication on acceptance

- Inclusion in PubMed, CAS, Scopus and Google Scholar

- Research which is freely available for redistribution

Submit your manuscript at www.biomedcentral.com/submit
Biomed Central 